TITLE:

\title{
Immature teratoma of the ovary: Correlation of MR imaging and pathologic findings(Abstract_要旨)
}

$\operatorname{AUTHOR}(\mathrm{S}):$

Yamaoka, Toshihide

\section{CITATION:}

Yamaoka, Toshihide. Immature teratoma of the ovary: Correlation of MR imaging and pathologic findings. 京都大学, 2003, 博士(医学)

ISSUE DATE:

2003-03-24

URL:

http://hdl.handle.net/2433/148679

RIGHT: 


\section{【271】}

\begin{tabular}{|c|c|}
\hline 氏 & $\begin{array}{llll}\text { やま } & \text { 招 } & \text { 兄 } & \text { ひで } \\
\text { 山利 } & \text { 成 }\end{array}$ \\
\hline 学位(専攻分野) & 博 士 (医 学) \\
\hline 学位記番号 & 医 博 第 2556 号 \\
\hline 学位授与の日付 & 平成 15 年 3 月 24 日 \\
\hline 学位授与の要件 & 学位規則第 4 条第 1 項該当 \\
\hline 研究科・専攻 & 医学研究科内科系専攻 \\
\hline 学位論文題目 & $\begin{array}{l}\text { Immature Teratoma of the Ovary: Correlation of MR imaging and } \\
\text { Pathologic Findings } \\
\text { (卵巣未熟奇形腫 : 核磁気共鳴画像所見と病理所見の対比) }\end{array}$ \\
\hline
\end{tabular}

\section{論文内容の要旨}

卵巣未熟奇形腫は，三胚葉成分由来の成熟・未熟組織からなる悪性腫瘍で，若年者に好発する。頻度は全卵巣癌の1\%未 満と稀であるが，二十歳までの卵巣癌の約15\%を占める。未熟組織の多宣にかかわらず，その存在で未熟奇形腫の診断が確 立するため，切除標本の十分な切り出しが極めて重要である。良性の成熟鐾胞性奇形腫が小児卵巣腫瘍の大半をしめる中で， 極めて稀な未熟奇形腫の可能性を術前に示唆することは治療法の選択，切除標本サンプリングの両者に影響し臨床的意義が 大きいと考元，未熟奇形腫の MR 所見の検討と病理組織学的所見との対比を試みた。

（対象と方法）1992年12月から2000年12月の間に，MR 検査が行われ病理診断が確定した10症例（12-29歳）をデータベ 一スから検索した。装置は GE 社製 Signa 1.5T $(\mathrm{n}=7)$ ，同 0.5T $(\mathrm{n}=3$ ) 超伝導 MR を用いた。スライス厚は 5一7mm, スライス間隔 $1-3 \mathrm{~mm}$ とし, 全例で矢状断面 $\mathrm{T} 1$ 強調画像, $\mathrm{T} 2$ 強調画像, 造影後 $\mathrm{T} 1$ 強調画像が撮影され, うち 6 症例で は脂肪抑制法が併用されていた。病理診断確定後に 3 名の放射線科医でMR 画像を 1) 腫瘍径，2）形，3）囊胞部分の 信号強度，4）充実成分の有無と特徵，5）脂肪の有無と特徵，6）腹水や播種巣の有無について検討した。また，画像上， 充実成分の占める割合により，充実成分優位，囊胞成分優位，両者の中間と 3 群に分類した。手術は全例，撮影後 2 週間以 内に施行された。病理診断では腫瘍の悪性度を未熟神経外胚葉組織の量に従い, Grade1から 3 に分類した。画像上の充実 成分の占める割合と組織学的な悪性度の相関を調べるため, Spearman の順位相関倸数を求めた。

（結果）腫瘍径は $10 \mathrm{~cm}$ から $21.5 \mathrm{~cm}$ ，平均 $15.5 \mathrm{~cm}$ であった。形態は表面平滑な卵形であった。囊胞部分の信号は水の信 号パターンを呈したものが 8 例，油脂のパターンが 1 例，両者の混在が 1 例であった。充実成分は全例に認められ，充実成 分が主体のものが 4 例，囊胞成分が主体のものが 5 例，雨者の中間が 1 例であった。充実成分の信号は $\mathrm{T} 1$ 強調画像では子 宮と等信号で，T2 強調画像では子㗬筋層と等信号からやや高信号で不均一な信号を呈していた。造影後 T1 強調画像では, 充実成分の中に微小襄胞構造が多数描出された。脂肪組織は充実成分の中に $1 \mathrm{~cm}$ 以下の皮下脂肪様の脂肪塊として全例に 認められた他，腫瘍辺縁部に油脂としても認められたものが 2 例存在した。腹水は 6 例に認められ，内 3 例には播種が伴っ ていた。病理組織学的検討では Grade1 が 4 例, Grade2 が 4 例, Grade3 が 2 例であった。順位相関係数は $0.27 て ゙$ 充実成分 の量と組織学的未熟神経外胚葉組織の量には有意な相関を認めなかった。

(考察) 未熟奇形腫には微小囊胞からなる充実成分，充実成分内に散在する脂肪塊など，従来報告されている成熟囊胞性 奇形腫とは異なる画像所見が認められた。これら所見を認めた場合悪性を疑う必要があると考えられる。画像上の充実成分 の割合と病理組織学的悪性度とは相関しないが，MR 画像で術前に未熟奇形腫の可能性を示唆することにより，適切な治療 法の選択，切除標本の慎重な検討，正確な悪性度判定が可能になると考えられる。

（結論）稀な未熟奇形腫のMRI 所見の特徵が充実成分中の微小囊胞構造と微小脂肪塊であることを明らかにした。充実 成分の多臭は悪性度と相関しないが，MRで未熟奇形腫の可能性を予測することは可能と考えられる。 


\section{論文審査の結果の要旨}

良性の多い小児卵巣腫瘍のなかで，極めて稀な未熟奇形腫の可能性を術前に知ることは臨床的意義が大きいと考えられる。 病理診断の確定した卵巣未熟奇形腫の10症例につき，その MR 画像を 3 名の放射線科医で検討した。また，画像上，充 実成分の占める割合で，充実成分優位，囊胞成分優位，両者の中間と 3 群に分類し，組織学的な悪性度との相関を Spearman の順位相関係数を用いて検討した。

腫場径は $10 \mathrm{~cm} \sim 21.5 \mathrm{~cm}$ ，平均 $15.5 \mathrm{~cm}$ であった。形は表面平滑な卵形で，囊胞部分の信号は水の信号パターンを呈した ものが 8 例，油脂のパターンが 1 例，両者の混在が 1 例であった。充実成分の信号は T1 強調画像では子宮と等信号で, $\mathrm{T} 2$ 強調画像では子宮筋層と等信号からやや高信号で不均一な信号を呈していた。全例で腫瘍の充実成分中に微小囊胞構造 と微小脂肪塊が認められた。腹水は 6 例に，内 3 例には播種が伴っていた。以上のことより充実成分中の囊胞構造と脂肪塊

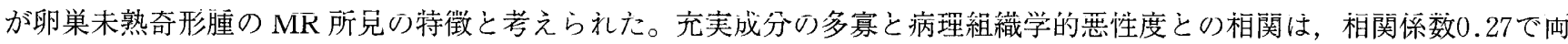
者に明らかな相関は認めなかった。

MR 画像で術前に未熟奇形腫の可能性を知ることにより，適切な治療法の選択，切除標本の慎重な検討，正確な悪性度判 定が可能になると考えられる。

以上の研究は未熟奇形腫の MR 所見の解明に貢献し，未熟奇形腫の診断・治療に寄与するところが多い。

したがって，本論丈は博士 (医学) の学位論文として価値あるものと認める。

なお，本学位授与申請者は，平成14年12月26日実施の論文内容とそれに関連した試問を受け，合格と認められたものであ る。 